Louw, DJ

University of Stellenbosch

\title{
Theopoiesis and the aesthetics of human dignity: towards a pneumatological approach
}

\begin{abstract}
The discourse on human dignity is most of the times determined by ethics and dogmatic issues. It is often the case that the paradigm of democratisation dictates processes of conceptualisation. The article operates from the hypothesis that aesthetics is more fundamental than ethics. Human dignity is a relational category determined by habitus and the eschatological status of our being qualities. In a pastoral theological approach one should shift from the democratic paradigm to the pneumatological paradigm. In this regard the theology of A. A. Van Ruler becomes most appropriate. Theopoiesis points to a kind of theological aesthetics within the realm of anthropology. The basic assumption of the article is that more fundamental than the moral question whether man is good or bad is the aesthetic question: the value and purpose of our being human; i.e. the human being as beauty (the dignity of human beings) or human beings as beast (the ugliness of human beings)? Human dignity is fundamentally an aesthetic category.
\end{abstract}

Hamlet (Shakespeare, Hamlet, Act iv, Scene III, p. 970) articulated the anthropological question regarding the quintessence of our being human as follows:

"What is a man,

If his chief good and market of his time

He but to sleep and feed? A beast no more."

\section{The CASE OF HAPPy Sindane: A RHINO WITHOUT A HORN ${ }^{1}$}

Happy Sindane was born to a white father and a Xhosa mother in 1984. Very little is known about his father, Henry Nick (German), who was his late mother's employer.

Sindane was thrown into the spotlight in 2003 when he claimed to be a white boy who had been kidnapped by black people. In 2003 he walked into a police station and told the bemused cops that he was a sixteen year old white boy who had been kidnapped and then raised by a black family. His quest was quite simple: he wanted to find his true family, to be returned to them, to reclaim his rightful childhood which was stolen from him. It was found by court that Happy's claim was a kind of "lie" in order to find identity. It was described by the magistrate as an "unintentional lie", a kind of provisional truth that was emotionally and psychically necessary, even though it might not been factual. This "unintentional lie" masked a child's refusal to accept his father's absolute rejection and his mother's disappearance. The lie was a kind of survival strategy in his desperate attempt to gain identity.

1 Case compiled by researcher from different reports on television and in media at the time of his death. 
NGTT: Oopbron - http://ngtt.journals.ac.za

After DNA tests, he was identified as Abbey Mzayiya, the son of a domestic worker, but chose to use the name Happy Sindane.

Sindane's body was found in a ditch early on Monday morning the $1^{\text {st }}$ of April 2013, less than 2 kilometres from his home. A passer-by found his battered body lying on a rocky, litter-strewn piece of veldt in Tweefontein, Mpumalanga. He had been stoned to death. There had been an altercation over a bottle of brandy at the JZee tavern where the dead man had been drinking. An empty bottle was found near the corpse.

A 58-year old man was arrested in connection with Sindane's murder. Sindane and the accused reportedly had a fight in a tavern over a bottle of brandy the night before he died.

During the court case it was pointed out that he grew up to be a 29-year old man but without challenges. He experienced no hugs and grew up like a rhino without a horn. He had no identity and if you remove a person's identity you take away their respect and dignity. The point is that bad things happened to Sindane in his short life and although he was a troubled boy, he did not deserve to die the way he had because killing Happy was like "killing an ant".

Sindane's biological siblings, the Mzayiyas of Diepsloot in Johannesburg, who requested to have him buried, next to his mother in the Eastern Cape, did not attend the funeral because they were not consulted about funeral arrangements.

At his funeral Sindane's grandmother Johanna Masombuka covered his coffin with a large blanket, a ritual performed in Ndebele culture. Magistrate Marthinus Kruger who presided over Sindane's custody matter in 2004, conducted the service, reading from Psalm 23.

The previous case study, clearly underlines the fact that human dignity is fundamentally a relational and aesthetic category. Human rights as such cannot guarantee human dignity.

Due to a lack of acknowledgement within the dynamics of human relationships, the public system and social networking, the life of Happy Sindane was "ugly": a rhino without a horn. In his quest for acceptance and dignity, he was forced into an "unintentional lie" in order to create the artificiality of a "provisional truth".

\section{HUMAN RIGHTS = HUMAN DIGNITY?}

Within the human rights discourse it is often extremely difficult to differentiate between human rights and human dignity. ${ }^{2}$ The discourse has become 'slippery'. Human dignity has even become an in-between issue: between sanctity and depravity (Witte Jr.2003 119-137); between man as beast and man as an angel (merely divine) (Meilaender 2009).

The debate on human rights focuses mostly on moral and democratic issues within the framework of personal, social and political ethics. Moltmann (1984) distinguishes between human rights ${ }^{3}$ as the quest for freedom, justice and equality, while dignity refers to how these

2 "The Reformed Theological Basis grounds human rights in human dignity and human dignity in humanity's being an image of God, and the being an image of God in God's right to human beings"

(Moltmann 1984:12). Kraynak (2003:81-118) devotes a whole article on the imago Dei in order to explain the connection between human dignity and the notion 'Made in the Image of God'.

3 Rawls (2003:197-198) identifies two principles of justice. 1. Each person has an equal right to the most extensive scheme of equal basic liberties compatible with a similar scheme of liberties for all. 2. Social 
NGTT Deel 54, Nommers $3 \& 4$, September en Desember 2013

issues impact on the quality of life of the individual, the unique and particular person. "Human rights are plural, but human dignity exists only in the singular ... The dignity of humanity is the only indivisible, in alienable, and shared quality of the human being" (1984:9).

According to Huber (1996:114), ideas of human dignity and human rights have been shaped by a long historical development. Within early European tradition, the quest for human dignity was closely connected to the rank and status of particular persons in society. The concept dignity (dignitas) is therefore a social category related to that of honour (honor) (Huber 1996:115). The turn toward the human being as the centrum of the whole of cosmos was fed inter alia by the renaissance and the humanism of the Enlightenment. Due to the Kantian influence (human beings as autonomous rational beings), as well as the impact of the Enlightenment and processes of secularization, the notion of human autonomy put an "anthropocentric" worldview in the centre of the human dignity discourse.

Within an anthropocentric worldview, "dignity" has increasingly meant the worth of being human. "Dignitas became closely associated with humanitas as to be construed as a synonym. To be able to say what dignity is would be to describe the fundamental meaning of being human." (Meeks 1984:ix). Dignity presupposes the following: to behave in a humane way and to be human. "For this reason, dignity has become the key concept in the worldwide struggle for human rights." (Meeks 1984:ix).

Initially European humanism linked the notion of human dignity to the Christian concept of humans created in the image of God. Human beings became the microcosm of God, containing in them a multitude of choices. One can therefore say that the "modern age, which began with humanism, is characterized by the conviction that human dignity is anchored in the self, namely in one's rational talents" (Huber 1996:117). It was when the recognition of equal dignity of all human beings were incorporated within the politics of democratization and institutionalized by international law that the shift from dignity to human rights became a focal point for the discourse on the value and worth of human beings. The reason perhaps is that human dignity, however, requires human rights for its embodiment, protection, and full flowering (Meeks 1984:xi). One must therefore admit that without human rights, human dignity becomes a fleeting idea without concrete and contextual meaning.

In his book On Human Dignity, Jürgen Moltmann (1984:31) connects human rights and human dignity as if the two concepts are exchangeable. "Through the service of reconciliation, human dignity and right are restored in this inhuman world." However, the important question in the human rights debate is whether human dignity and human rights could be used as interchangeable concepts. Hence, the attempts to differentiate between the two concepts in order to understand better their interconnectedness. "Human rights spring from human dignity and not vice versa" (Meeks 1984:xi).

Within the theological discourse on human rights, the anthropological question regarding human dignity and human rights, evolve mostly around the hermeneutics of the imago Dei.

and economic inequalities are to meet two conditions: they must be (a) to the greatest expect benefit of the least advantaged and (b) attached to offices and the positions open to all under conditions of fair opportunity.

4 For Rombach (1987:379) dignity then describes the humane human being (Der menschliche Mensch); the human being shaped by the social processes of identity and meaningful space (Idemität $=$ a spiritual networking of meaning as the whole which gives significance to every particular part). 
NGTT: Oopbron - http://ngtt.journals.ac.za

According to Kraynak (2003:90), the problem with the notion of the imago Dei5 resides, in the fundamental difference between the biblical and the contemporary understanding of human dignity. "In the biblical view, dignity is hierarchical and comparative, in the modern, it is democratic and absolute" (Kraynak 2003:90). A further problem surfaces when the Biblical construct of the imago Dei does not refer so much to inherent ontological dignity, but to qualitative representation within the dynamics of relationships. As Kraynak (2003:91) pointed out: human dignity is a relational category, "it is also something to be won or lost, merited of forfeited, augmented or diminished".

Within the tradition of Plato, Aristotle and Kant, dignity could be related to intelligibility. ${ }^{6}$ It then resides in the human nous or mind. Eventually dignity and rights become qualities of radical autonomy. "But the Imago Dei has now been given a new twist, which includes the ethical imperative to affirm the rights and dignity of the self-defining person" (Kraynak 2003:112).

Meilaender (2009:8) distinguishes between two concepts of dignity: human and personal. Human dignity then has to do with the powers and the limits characteristic of our species - a species marked by the integrated functioning of body and spirit. Personal dignity refers to the individual person whose dignity calls for our respect whatever his/her powers and limits may be. Although human dignity refers to many layers of meaning, Meilaender (2009:89) points to equal respect as a principle and theoretical basis for human dignity. Human dignity is also connected to the notion of virtue (Meilaender 1984).

Albeit, one should agree with Meeks (in Moltmann 1984:ix) that 'dignity' is a difficult word to define. It is often used as an exchangeable concept for human rights. "For this reason, dignity has become the key concept in the worldwide struggle for human rights" (Meeks in Moltmann 1984:ix), a struggle embedded in different cultural contexts and deep ideological disagreements over human rights. The further problem is that dignity defined in many different ways immediately entails a counter-definition of others as inhuman, not possessing dignity.

What then is 'human' in human dignity and human rights? Especially, if one takes Hobbes' notion about the wolf in human nature seriously: homo homini lupus (Negt 2003:31).

In the debate on a theological approach to anthropology, theologians very aptly point out the notion of human sin and the connection between the corruptio totalis ${ }^{7}$ and human fallibility. In many cases the reason why Christian spirituality was hesitant to be engaged in the debate on human dignity and human rights, was the use of the notion of the fall as starting point for a theological anthropology. For example, the anthropological notion of creation and the 'image of God' stir up the debate on the doctrine of sin. Hence, the shift in many "enlightened"

\footnotetext{
5 "In reflecting on the Christian view of human dignity, scholars commonly begin with the biblical references to the Imago Dei - to the image of God in man. For example, Reinhold Niebuhr argues in The Nature and Destiny of Man that the human quality most reflective of the divine nature is "selftranscendence": the capacity to rise above our natural selves and freely construct a world of higher meanings". Kraynak 2003:83.

6 "On one common reading, "dignity" refers to a basic faculty; it denotes the bare capacity for intelligent free choice shared equally by all non-damaged persons. One's rational freedom may be misused, but the simple possession of it is the ground of respect" (Jackson 2003:143).

7 See the impact of St Augustine in this regard. Human beings are robbed from their super human gifts or dignity due to a peccatum originale. Sin robbed human beings from their original freedom. See Rebel $1981 ; 171-174$.
} 
NGTT Deel 54, Nommers $3 \& 4$, September en Desember 2013

theological circles on human rights to withdraw of the doctrine of original sin in order to describe a theological anthropology beyond the categories of the fall. "The more uninhibited and optimistic the talk was regarding the dignity and abilities of humans, the greater was the need to relativise and secularize the doctrine of original sin. The doctrine appears - in the form of insight into the finiteness and fallibility of humans - merely as a limiting condition of human self-realization, no longer a description of the very essence of humans" (Huber 1996:120).

In systematic theology human dignity is mostly viewed as an ethical issue and not as an aesthetics issue. For example, W Huber (1996:xvi) links human dignity and human rights to an "ethics of human dignity". "Human dignity is a packed-up ethical argument. Its lofty status can be recognized from the way in which it is written into the texts of constitutions" (AmmichtQuinn 2003:39).

My argument is that human beings should be assessed in the first place within aesthetic categories and not from the perspective of ethical categories (morality and sinfulness). Theological ethics emanates from theological aesthetics. ${ }^{9}$

Ethos refers to virtue and attitude, conduct and habitus, ${ }^{10}$ the essential make up and characteristics of something (human identity). Ethos refers to the aesthetics of identity and dignity. In this case identity represents the unique personal, individual characteristics of a human being (our calling and vocation), while dignity reflects personal self-value and selfimage as related to meaning and worth.

Aesthetics without ethics is not possible. While ethos is connected to the aesthetics of value and meaning, ethics represents the normative framework of life; it gives direction to ethos and represents the imperative within the indicative of aesthetics. Ethics represents the normative framework for meaningful living. However, being (Dasein) and the mode of human existence (So-sein) are in a spiritual approach to anthropology more fundamental than doing.

A theological aesthetics reckons with two important categories: doxa and charisma. Within a Christian spiritual approach dignity should be linked to habitus as a reflection of the glory of God. "Glory (doxa) is the closest word to dignity in the New Testament" (Kraynak 2003:93).

Dignity is not a value inherent to the person (Hobbes ${ }^{11}$ in Negt 2003:30); dignity is a relational category. "So dignity is not an attribute peculiar to persons and their singularity; it is a relationship, or rather manifests itself in the gesture by which we relate to others to consider

8 "In this book I hope to clarify what an ethics of human dignity can contribute to this debate, in particular the potential within Jewish and Christian traditions for an adequate approach to this topic." Huber 1996:xvi.

9 For a discussion on a theological aesthetics, see Murphy 2008:5. Hans Urs von Balthasar founds his theological aesthetics on the insight that being has been overcome by the beauty of Christ. "For what von Balthasar asks us to accept is not simply that our (humanly) inspired experiences of Beauty resonate analogously with the divine Beauty (or, more precisely, that they are always already shaped by the resonance within them of the divine Beauty of the incarnation), but that there is a further analogy between our critical and scholarly reflections on these human experiences and the way in which we should be reflecting theologically on the Divine Beauty" (Pattison 2008:109-110).

10 In 1983 already, Edward Fairley advocated the understanding of practice in Practical Theology as habitus. Theologia practica is for him habitus: "Practice meant that aspect of the habitus or wisdom in which the divine object sets requirements of obedience and life (1983:27).

11 For Hobbes dignity is bound up with power and domination. See Negt 2003:30. 
NGTT: Oopbron - http://ngtt.journals.ac.za

them human, just as human as we are, even if their appearance suggests non-humanity, indeed inhumanity" (Valadier 2003:55). I cannot 'claim' dignity, I am dignity. I dignify my life by means of the quality of habitus and informed responsible decision-making.

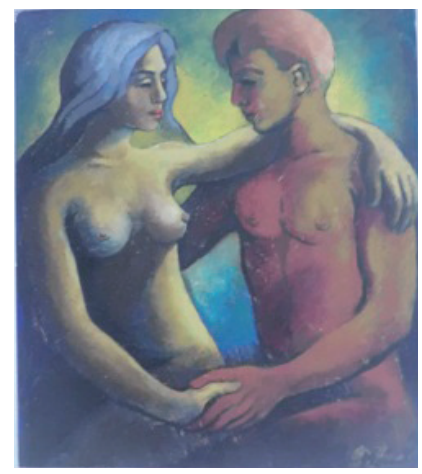

Young Lovers (Jong Minnaars) by Johannes Meintjies 1954. Photo: D. J. Louw. Permission: High School Molteno. In the embracement of the female and male, nudity becomes beautiful and both of the two human beings become dignified. The embracement makes them free from all gender categories. They are not anymore female and male, but two human beings transformed into a new identity within the aesthetic framework of love. The change is reflected in their habitus towards one another; their dignity regarding human embodiment and sexuality becomes a relational issue.

Dignity is in essence a spiritual category. It refers to meaning and the quality of life. As a spiritual category within the framework of a Christian reflection on anthropology, one cannot avoid the notion of grace and unconditional, sacrificial love (the eschatological qualification), as well as the notion of the fruit of the Spirit (charisma) (the pneumatological qualification). Hence, our assumption that human dignity and human rights reside as spiritual categories in the fact that dignity is enfleshed in human bodies due to the indwelling presence of the Holy Spirit; human dignity is a matter of inhabitational theology.

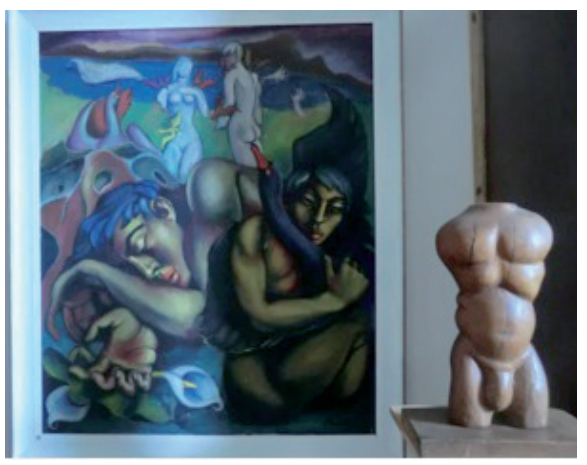

Spiritual dignity (inhabitational dignity) as reflected in the male torso (Johannes Meintjies) as well in the bodies of the painting (Ikaros, Johannes Meintjies 1948). Photo: D. J. Louw.

Permission: Molteno Highschool. 
What it means to be truly human is closely connect to the fact that human beings live in the presence of God and are created in the image of God: "The image of God is human rights in all their relationships in life" (Moltmann 1984:23). "Thus in God's liberating and redeeming action the original destiny of human beings is both experienced and fulfilled. In the 'image of God' concept, the divine claim upon human beings is expressed" (Moltmann 1984:22). ${ }^{12}$

Our point of departure for a theological understanding of human dignity is not in the first place the creation paradigm but the re-creational paradigm of eschatological thinking. Human dignity is promised to human beings by "God's justifying grace" (Huber 1996:119).

Eschatology views human beings from the perspective of who we already are in Christ. Our identity is determined by salvation and grace. We are accepted unconditionally for who we are. It is not what we do that is fundamental for the quality of ethos, but who we are. The indicative of salvation determines the imperative, which emanates from the eschatological character of salvation.

"The imperative does not appeal to Christian's good will or ability, but recalls what they have already received in baptism: freedom and a new Lord" (Schrage 1988:176).

What is therefore required is not that we do something, but that we be something (some-body) (Schrage 1988:43). The crucial point is the transformation and metanoia ${ }^{13}$ of the individual (transformation of stance, conduct and orientation, the telos of life) in terms of intention, motivation and goal. Thus Schrage's conclusion that Jesus' ethics was an ethics of intention (1988:43).

The salvific nature of the kingdom of God determines our ontological stance in both life and death. The character of the kingdom determines human conduct (Schrage 1988:37).

Ethics is a consequence of eschatology and not a precondition. In this way an eschatological approach undermines perfectionism and legalism. What is most needed is wisdom (sapientia) in order to beautify human life; the aesthetics of unconditional love. "Presence embodies grace" (Augsburger 1986:36). ${ }^{14}$

Within a pneumatological paradigm the human being is not assessed in terms of an opportunistic approach, which implies that all relationships are fine when they only embody God's presence through empathetic responses. In an opportunistic approach the focal point is merely individual need satisfaction and the maintenance of basic human rights.

Neither is humans assessed in terms of a pessimistic approach, which implies that human beings are merely sinners and doomed to failure.

12 Huber (1996:117) refers to the Italian humanism of the fifteenth century who built the notion of human dignity upon the concept of humans created in the image of God.

13 Metanoia in the Greek is not to be understood in a purely intellectual sense. "It means not just a change of mind about something but also a change of attitude, of intention, of will, if not a total transformation of one's conduct and orientation" (Schrage 1988:41-42).

14 Empathy as an emotional mode of incarnating the love of God becomes the norm for the quality of the pastoral intervention. "Pastoral counselling across culture is rooted in an incarnational theology that is truly present to others and a dialogical theology that is open to others in agape" (Augsburger 1986:36). 
NGTT: Oopbron - http://ngtt.journals.ac.za

In a pneumatological approach human beings are assessed realistically and relationally. A realistic approach in spirituality means that as Christians we are already new beings in Christ. In Christ humans are endowed with the fruits of the Spirit (Gal. 6:22-26). Human beings in Christ are "charismatic human beings". ${ }^{15}$ The reality of the fruit of the Spirit implies a pneumatological ontology: one is (eschatological speaking) ${ }^{16}$ therefore love. From a pneumatological point of view, love - as in the case of all the fruit of the Spirit - is now a being function and aesthetic category. "Do you not know that your body is a temple of the Holy Spirit, who is in you, whom you have received from God?"(1 Cor. 6:19).

It was Aristotle who underlined the importance of virtues for purposeful actions. To this end he identified four basic virtues — prudence, justice, temperance and courage.

It is indeed true that Aristotle's and Homer's understanding of arete differs from that of the New Testament. The New Testament not only promotes virtues such as faith, hope and love, but views humility (the moral for slaves) as one of the corner-stones in the formation of a Christian character (Maclntyre; 19842:245). Maclntyre's conclusion (19842:249) is of importance to the debate on the interplay of values and virtues. In both the New Testament's and Aristotle's comprehension, despite differences, virtue ${ }^{17}$ has this in common: it empowers a person to attain that characteristic essential for attaining meaning and significance (telos).

It is a fact that the notion of relationality was often questioned as a reliable and valid approach. The critical point is then that human beings often act in relationships with enmity, hatred, anger and violence rather than with unconditional love. Our love is most of times conditional. The terse slogan that man is wolf to man (homo homini lupus) is from a sociological point of view indeed relevant. However, it will later be argued that from a pneumatological point of view, theology should revisit the slogan: "man is man to man" (homo homini homo); the term "human" then stands for the capability to have empathy, solidarity, and cooperation (in Huber 1996:118).

'Identity', as derived from the Latin idem indicating the same, conveys the idea of continuity. Identity presumes a continuity between the human I and behaviour, hence, the importance of congruency. Congruency happens when the self is a true reflection and portrayal of the conduct and experiences of the human I. Congruency is about remaining faithful to oneself, communicating authenticity and truth (Heitink 1977:69). It is about the question to what extent one's belief system correlates with actions, lifestyles and behaviour.

The answer to the question: 'Who am I?' depends on the quality of the human reaction, and on the degree and quality of human responsibility. Our basic point of departure is therefore the core principle that qualifies ethos (attitude and aptitude) in human behaviour: respondeo ergo sum. In essence human dignity is a pastoral category and not merely a dogmatic formulation or moral issue within the framework of ethics; it resides in habitus.

One could say that humanity and humanness refer to the character of our human freedom, i.e.

15 Charisma is not a human potential. It points to the work of the Spirit. (Schrage 1988:179)

16 Ashley and O'Rourke (1994:196) also opt for the eschatological aspect of ethics: "This is why we have opted for a teleological, goal-directed, means-ends ethics".

17 Kreeft (1986:192) implies that virtue is necessary for the survival of civilization, while religion is necessary for the survival of virtue. Without moral excellence, right living, goodness, purity, chastity and effectiveness, our civilization is on the road to decline. Civilization needs justice, wisdom, courage and temperance. 
NGTT Deel 54, Nommers 3 \& 4, September en Desember 2013

our ability to take responsibility for life and to make responsible decisions that will enhance the quality of life. It is indeed true that humanity cannot be separated from moral decisionmaking. Animals do not make moral choices. However, humanity and dignity entails more. It touches the quality of the "human soul" and the character of our "ego" and being functions...

Humanity refers to the fact that humans can say: "I". Personhood indicates an ego with the potential of awareness (consciousness - subconsciousness). Within this ego there are several components: the cognitive component of the human mind and reflection; the affective component of emotions; the conative component of will power, the social component of relationships, the environmental dimension of culture, the ethical dimension of morals, virtues/vices, norms and values, the spiritual dimension of meaning and the corporeality of human embodiment.

To capture the gist of my argument, one can say that:

- $\quad$ Dignity (dignitas) within a social paradigm (still mostly hierarchical) points to role function, status, position and authority. In this regard acknowledgement (freed from prejudice, discrimination and stigmatisation) plays a decisive role. Dignity also points to different degrees and levels of need-satisfaction.

- $\quad$ Dignity (dignitas) within an ethical paradigm points to equality, justice and rights within the quest for liberation. Thus the important question about the quality of freedom and justice.

- $\quad$ Dignity (dignitas) within an aesthetic paradigm points to meaning, telos (purposefulness/destiny/significance) and intimacy: the basic quest to care for the humanum. As an aesthetic category dignity relates to care, nurture, comfort, empathy, interpathy, reconciliation and forgiveness. Dignity therefore presupposes to a large extent to the dimension of healing and human well-being. As a spiritual category, the aesthetics of dignity is dependent on the quality of intimacy; i.e. to be accepted unconditionally for who you are without the fear of rejection. Anxiety, the fear for rejection, isolation and existential loneliness, is the most basic threat to human dignity and human health. It is even more devastating than guilt and despair.

The previous outline pointed out several categories within what one can call the dynamic networking of human dignity. It has been argued that human rights cannot be separated from human dignity. At the same time, both dignity and rights are closely related to the identity of the people involved.

But how are all the components, regarding the complex networking of identity, dignity and rights, connected to one another and therefore interrelated?

\section{SeEing the Bigger Picture Of IDENTITY}

In order to see the bigger picture of identity, one can say that identity oscillates between the level of individuality on the one hand (uniqueness) (differentiation: introspection and self-insight regarding personal strengths and weaknesses), and on the other hand a sense of interconnectedness and self-acceptance/self-confidence. Identity also presupposes a kind of autonomy and responsible decision-making in the light of visionary thinking (vision). At the same time it is embedded in sensitivity and wisdom, i.e. the capacity to discern what appropriate behaviour is about and what inappropriate behaviour is about. The quality of 
NGTT: Oopbron - http://ngtt.journals.ac.za

one's sensitivity correlates with personal commitments and convictions; it describes one's passion in life.

The following diagram helps to see the unseen dynamics of human identity. It helps one to understand why disappointment (things did not work out as expected) and prejudice (exclusive perceptions that disqualifies the other and "marks" the other as less acceptable; it then fuels a downward spiral of destructive comparison and negative devaluation) can rob one from one's human dignity. Prejudice as a social construction easily leads to other components such as labelling, stereotyping, cognitive separation, destructive emotional reactions, status loss, stigmatisation and discrimination. In fact, prejudice is a kind of antipathy based on faulty and inflexible generalisations; it leads to exclusive marginalisation. Together with stigma, prejudice conveys a devalued social identity. A person who is stigmatised is a person whose social identity or membership in some social category, calls into question his or her full humanity. As in the case of Happy Sindane, the person is eventually devalued, spoiled or flawed in the eyes of others.

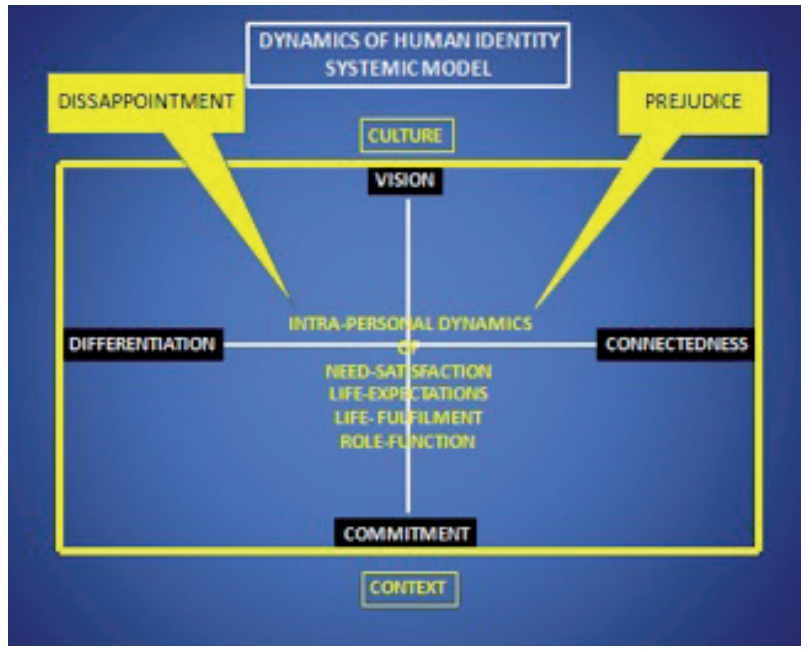

It is clear that both identity and dignity are closely related to both the quality of a human being's attitude (ethos) and moral awareness regarding what is right and what is wrong (ethics). The quality of decision-making, one's philosophy in life (commitments), one's personal capacity (gifts/charisma) and one's vocation and vision will play a fundamental role within the networking of human dignity and human identity.

Human dignity (care for the value of life) and identity (habitus: the respond-able and sensitive human I; ethos: a sacrificial stance in life) determine the quality of human rights (the normative framework of life within the communality of a spiritual humanism). In order to prevent human rights of becoming sheer political ideology or merely an abstract and even legalistic imperative within processes of democratization and liberation, human rights should be determined by human dignity. This emphasis on human dignity should rediscover the worth of our being human within the aesthetics of a suffering God..$^{18}$

18 In a theological aesthetics, beauty should be connected to the pathos of the crucifixion. On Christ's 
NGTT Deel 54, Nommers $3 \& 4$, September en Desember 2013

The praxis-question in anthropology should eventually reside in pneumatology and not predominantly in Christology. For this paradigmatic shift the theology of the Dutch theologian A. A. van Ruler is most relevant and should be revisited. Why? Within incarnation theology the human being is nothing (homo peccator) and God is everything (sacrificial grace): Christ is mediator. Christology is about redemption. In inhabitational theology, man, the human being, is becoming 'whole' (homo aestheticus) and therefore "everything" (humanum); human beings are not excluded in salvation (heil, shalom), but totally incorporated (Rebel 1981:209) because the humanum is now determined by pneuma.

\section{THEOPOIESIS: THE BEAUTY OF THE SPIRIT}

In terms of pneumatology Van Ruler points to the category of theopoiesis (Rebel 1981:145). Theopoiesis means that the human will starts to correspond with the divine will according to the indwelling presence of the Spirit. The human person starts to become theonomous and therefore fully authentic and autonomous; i.e. it displays the charisma of the Spirit (the soulfulness of embodied humanism). Van Ruler (1968:12) calls our pneumatic identity: the capacity and ability that humans become "whole" and therefore merely "divine"; humans are in themselves theo-logos (Ik ben theo-logos, Godzegger). To build in any concurrency between God and human beings is pagan idolatry (Rebel 1981:99); pneumatology rather creates a theological osmosis (Van Ruler in Rebel 1981:85) between God and human beings. Sin is secondary, eschatological being is primary. In an Christological anthropology, the object of faith is salvation (heil= becoming whole); in a pneumatic anthropology, the object of salvation is the humanum (Rebel 1981:140).

The implication of this pneumatological understanding of the humanum is that human dignity is a spiritual and inclusive category. It includes the beauty of the human body. Spirituality without human embodiment becomes unreal; embodiment without spirituality is exposed to nausea and non-sense. The body can indeed be called the eikōn of the human soul.

\section{BIBLIOGRAPHY}

Ammicht-Quinn, R. 2003.Whose Dignity is Inviolable? Human Beings, Machines and the Discourse of Dignity. In Regina Ammicht-Quinn, Maureen Junker-Kelly, Esa Tamez (eds.): The Discourse of Human

Dignity. London: SCM Press, pp. 34-45.

Augsburger, David W. 1986. Pastoral Counseling across Cultures. Philadelphia: Westminister.

Ashley, B., K. D. O'Rourke. 1994. Ethics of Health Care. Washington: Georgetown University Press.

Fairley, E. 1983. Theology and practice outside the clerical paradigm. In: D. S. Browning (ed.) Practical

Theology. San Francisco: Harper and Row.

Garcia-Rivera, A. 2008. On a New List of Aesthetics Categories. In: O. V. Bycgov, J. Fodor (eds.), Theological Aesthetics after von Balthasar. Aldershot: Ashgate, pp.169-183.

Heitink, G. 1977. Pastoraat als hulpverlening: Inleiding in de pastorale theologie en psychologie. Kampen: Kok.

Huber, W. 1996. Violence. The Unrelenting Assault on Human Dignity. Minneapolis: Fortress Press.

Jackson, T. P. 2003. A House Divided Again: Sanctity vs. Dignity in the Induced Death Debates. In: R.

P Kraynak, G Tinder (eds.), Defense of Human Dignity. Essays for our Times. Nortre Dame, Indiana:

University of Notre Dame Press, pp.139-163.

Kraynak, R. P. 2003. "Made in the Image of God": The Christian View of Human Dignity in Protestant

suffering see the remark of Garcia-Rivera (2008:177): “This em-pathos, mediated by their own distinct accounts through the beauty of the crucifix, in turn becomes, second, syn-pathos - a plea for divine sympathy with their own suffering". 
NGTT: Oopbron - http://ngtt.journals.ac.za

Perspective. In: R. P Kraynak, G Tinder (eds.), Defense of Human Dignity. Essays for our Times. Nortre Dame, Indiana: University of Notre Dame Press, pp. 81-118.

Kreeft, P. 1986. Back to Virtue. San Francisco: Ignatius.

Maclntyre, A. 1984. Der Verlust der Tugend. Zur moralische Krise der Gegenwart. Frankfurt: Campus Verlag.

Meeks, M. D. 1984.Introduction. In: J. Moltmann, On Being Human. London: SCM Press, pp. ix-xiv.

Meilaender, G. C. 1984. The Theory and Practice of Virtue. Notre Dame (Indiana): University of Notre Dame Press.

Meilaender, G. C. 2009. Neither Beast nor God: the Dignity of the Human Person. New York: Encounter Books.

Moltmann, J. 1984. On Human Dignity. Political Theology and Ethics. London: SCM Press.

Murphy, F. A. 2008. Hans Urs von Balthasar: Beauty as Gateway to Love. In: O. V. Bycgov, J. Fodor (eds.), Theological Aesthetics after von Balthasar. Aldershot: Ashgate, pp. 5-17.

Negt, O. 2003. The Unrepeatable: Changes in the Cultural Concept of Dignity. In Regina Ammicht-Quinn, Maureen Junker-Kelly, Esa Tamez (eds.): The Discourse of Human Dignity. London: SCM Press, pp. 2534.

Pattison, G. 2008. Is the Time Right for a Theological Aesthetics? In: O. V. Bycgov, J. Fodor (eds.), Theological Aesthetics after von Balthasar. Aldershot: Ashgate, pp. 107-114.

Rawls J. 2003. A Well-Orderd Society. In: R. P. Kraynak, G Tinder (eds.), Defence of Human Dignity. Essays for our Times. Nortre Dame, Indiana: University of Notre Dame Press, pp. 193-206.

Rebel, J. 1981. Pastoraat in pneumatologisch perspektief. Een theologisch verantwoording vanuit het denken van A. A van Ruler. Kok: Kampen.

Rombach, H. 1987. Struktur-anthropologie. "Der menschlich Mensch". Freiburg/München: Verlag Karl Alber. Schrage, W. 1988. The Ethics of the New Testament. Philadelphia: Fortress Press.

Shakespear, W. 1968. Macbeth. The Complete Works of William Shakespeare. Comprising his Plays and Poems. Middlesex: Springbooks.

Valadier, P. 2003. The Person who lacks Dignity. In Regina Ammicht-Quinn, Maureen Junker-Kelly, Esa Tamez (eds.): The Discourse of Human Dignity. London: SCM Press, pp. 49-56.

Van Ruler, A.A. 1968. Ik geloof. De twaalf artikelen van het geloof in morgenwijdingen. Nijkerk: Callenbach. Witte J. R., J. 2003. Between sanctity and depravity: Human Dignity in Protestant Perspective. In: R. P. Kraynak, G. Tinder (eds.), Defense of Human Dignity. Essays for our Times. Nortre Dame, Indiana: University of Notre Dame Press, pp. 119-138.

\section{KEY WORDS}

The aesthetics of human dignity

Human rights

Human dignity

Theological anthropology

Pneumatology and Theopoiesis

Inhabitational theology

\section{TREFWOORDE}

Die estetika van menswaardigheid

Menseregte

Menswaardigheid

Teologiese antropologie

Pneumatologie en Theopoiesis

Inwonende teologie

Prof. D. J. Louw

Faculty of Theology

University of Stellenbosch

171 Dorp Street

Stellenbosch

djl@sun.ac.za 